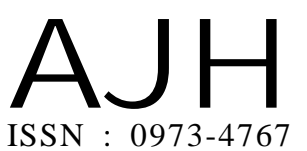

Article history :

Received : 23.01.2020

Revised : 01.05.2020

Accepted : 18.05.2020
RESEARCH PAPER

DOI : 10.15740/HAS/TAJH/15.1/1-3

\section{Impact of nitrogen and phosphorus on growth and seed yield of spinach (Spinacia oleracea L.)}

\author{
Navdeep Singh and Harpal Singh ${ }^{1}$
}

\begin{abstract}
The present investigations entitled "Impact of nitrogen and phosphorus on growth and seed yield of Spinach (Spinacia oleracea L.)" was carried out in experimental area of research farm of Guru Kashi Univesity, Talwandi Sabo (Bathinda) during Rabi season 20182019. The experiment was laid out in Randomized Block Design (RBD) keeping doses in combination with different rates of nitrogen $\left(0,35,70\right.$ and $\left.95 \mathrm{~kg} \mathrm{ha}^{-1}\right)$ and phosphorus $(0,15,30$ and $45 \mathrm{~kg} \mathrm{ha}^{-1}$ ) on growth and seed yield of spinach. Results showed that the maximum height of plant was $84 \mathrm{~cm}$, number of branches 10.94 and weight of 100 seeds was 1.30 gram was recorded with the combined application of $95 \mathrm{~kg} \mathrm{~N} \mathrm{ha}^{-1}$ and $45 \mathrm{~kg} \mathrm{P}_{2} \mathrm{O}_{5} \mathrm{ha}^{-1}$. Maximum seed yield per plant 6.36 gram and seed yield $285.52 \mathrm{~kg} /$ ha were obtained from $95 \mathrm{~kg} \mathrm{~N}^{-1}$ and $0 \mathrm{~kg} \mathrm{P}_{2} \mathrm{O}_{5}$ $\mathrm{ha}^{-1}$.
\end{abstract}

KEY WORDS : Nitrogen, Phosphorus, Spinach

HOW TO CITE THIS ARTICLE : Singh, Navdeep and Singh, Harpal (2020). Impact of nitrogen and phosphorus on growth and seed yield of spinach (Spinacia oleracea L.). Asian J. Hort., 15(1) : 1-3, DOI : 10.15740/HAS/TAJH/15.1/1-3. Copyright@2020 : Hind Agri -Horticultural Society
Author for correspondence : Navdeep Singh

Department of Vegetable Science, University College of Agriculture, Guru Kashi University, Talwandi Sabo, Bathinda (Punjab) India Email : navdeep.brar50@gmail.com
Volume $\mathbf{1 5} \mid$ Issue $1 \mid$ June, 2020 | 1-3
Visit us -www.researchjournal.co.in
Members of the Research Forum

${ }^{1}$ Department of Vegetable Science, Guru Kashi University, Talwandi Sabo, Bathinda (Punjab) India 